\title{
Chapter 8 \\ Rotterdam as a Case of Complexity \\ Reduction: Migration from Central \\ and Eastern European Countries
}

\author{
Erik Snel, Mark van Ostaijen, and Margrietha 't Hart
}

Various authors have described the Netherlands as a 'reluctant country of immigration'. Although the Netherlands was de facto an immigration country, until recently it seemed unwilling to admit it (Cornelius et al. 2004; Muus 2004; Van Meeteren et al. 2013). Similarly, with 174 different nationalities in the city, Rotterdam is characterised by 'superdiversity' (Vertovec 2007). But unlike cities such as London or Amsterdam who celebrate their diverse populations, Rotterdam is rather reluctant to do so. Rotterdam local politics and local policies seldom welcome ethnic and cultural diversity in the city. They rather underline the problems related to the presence of migrants and their families, particularly when they live concentrated in certain Rotterdam districts. This reluctance is also apparent in the reaction of Rotterdam authorities to the arrival and settlement of new migrants from Central and Eastern Europe in the aftermath of the EU-enlargement in 2004, the central topic of this chapter. Although statistics about the size of Central and Eastern European (further CEE) migrants and how many families actually live in the city are contested, Rotterdam authorities estimated their numbers to be up to 50,000 (Municipality Rotterdam 2015).

However, as Vertovec (2007: 1025) stresses, superdiversity is not only about more ethnicities or nationalities in receiving communities, but it is also about a "multiplication" of other relevant variables such as differential immigration statuses or labour market outcomes. As we shall argue, CEE labour migrants in Rotterdam are a diverse population in various respects. Firstly, in terms of temporality. Although many CEE labour migrants are typical temporary or 'circular' migrants, who travel

\footnotetext{
E. Snel $(\bowtie) \cdot$ M. 't Hart

Department of Public Administration and Sociology (DPAS), Erasmus University Rotterdam, Rotterdam, The Netherlands

e-mail: snel@essb.eur.nl

M. van Ostaijen

Tilburg School of Governance, Tilburg University, Tilburg, The Netherlands

e-mail: m.vanostaijen@uvt.nl
} 
up and down between sending and receiving countries, a growing number of them settle more permanently in the Netherlands (Engbersen et al. 2013). Secondly, in terms of socio-economic status. CEE labour migrants are also diverse in terms of their labour market positions. Although many of them work in low-skilled, low-paid and often flexible jobs, and sometimes in informal work arrangements, some CEE labour migrants have relatively high occupational positions. They work as IT specialists, dentists or as scientific researchers (Engbersen et al. 2013). This shows that the popular image of CEE labour migrants as workers at 'the bottom' of the urban labour markets is too simplistic. Despite these multiple diversities, this chapter will argue that the Rotterdam political debates and local policies regarding CEE migrants seem to rely on complexity reduction, especially regarding its temporality and socio-economic status. Rotterdam policies mainly focus on temporary low-skilled workers and the (alleged) problems related to this category (such as flexible work relations, exploitation by irregular temporary employment agencies, uncertain housing conditions in overcrowded accommodations, with disorder and public nuisance as a result, etc.) while neglecting the fact that other CEE labour migrants and their families live in Rotterdam in far more stable conditions.

This chapter consists of four parts. The first part discusses what we know from previous research about the social and economic position of CEE migrants in the Netherlands and more specifically in Rotterdam. The second part maps how the city of Rotterdam responds to these 'new' migrant groups in the city by means of local policy efforts. One recurring issue on the Rotterdam agenda, as we shall see, relates to (alleged) nuisance caused by CEE labour migrants in already vulnerable Rotterdam districts where they live. The third part of this chapter, based on administrative data from Rotterdam, examines whether the influx of CEE nationals in Rotterdam districts has indeed resulted in increased numbers of registered incidences of nuisance and/or in the increased perceptions of disorder among neighbourhood residents. We conclude with some general remarks about the Rotterdam policy approach on CEE migration.

\subsection{CEE Migrants in Rotterdam}

Rotterdam has always been a city of immigrants. In the late nineteenth century, Rotterdam expanded rapidly from being a small town with 90,000 residents to a major city with over 300,000 residents. This rapid population increase was mainly due to the massive influx of internal labour migrants and their families from the southern Dutch provinces, Brabant and Zeeland; these migrants were, so to say, early 'allochthonous' (literally: from another territory) in Rotterdam. Like so many West-European cities, Rotterdam received a second wave of labour migrants and their families in the 1960s and 1970s. These so-called 'guest workers' mainly came from Mediterranean countries such as Turkey and Morocco. And now, Rotterdam is experiencing a third period of migrant workers, this time from the new EU-member states in Central and Eastern Europe. 


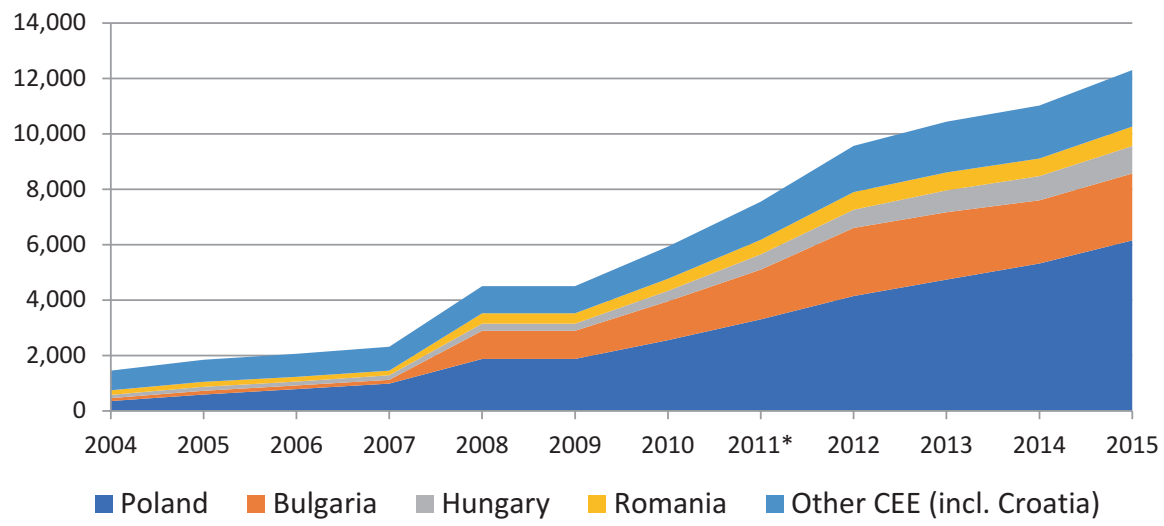

Fig. 8.1 EU-nationals from Central and Eastern European countries in Rotterdam (2004-2015). (Source: Municipality of Rotterdam (OBI))

The first CEE labour migrants arrived in Rotterdam already before 2004, the year of the first EU-enlargements. ${ }^{1}$ In January 2004, 1450 CEE nationals were officially registered in the city. Although the municipal statistics do not tell us what these CEE nationals did at the time, we can assume that most of them were labour migrants, particularly from Poland. Already in the 1990s, the Dutch government signed an agreement with Poland that enabled Polish workers to be employed in the agriculture and horticulture sector. As a result of this agreement, thousands of temporary workers came to the Netherlands to work in the horticultural industry such as in the municipality of Westland (Sert 2014). Most likely, some of these temporary migrant workers were housed in Rotterdam. Between 2004 and early 2015, the total number of registered CEE nationals in Rotterdam increased from 1450 to $12,300 .^{2}$ About half of the CEE nationals in Rotterdam came from Poland, but the city also hosts relatively large numbers of Bulgarians, Hungarians and Romanians (see Fig. 8.1). With a total population of 625,000 residents (early 2015), this implies that $2 \%$ of the total Rotterdam population is registered as 'CEE national'.

\footnotetext{
${ }^{1}$ In May 2004, Cyprus, Czech Republic, Estonia, Hungary, Lithuania, Latvia, Malta, Poland, Slovakia and Slovenia joined the European Union. In January 2007, Romania and Bulgaria also acceded to the EU, as did Croatia in January 2014.

${ }^{2}$ In this chapter we use data about the number of CEE nationals in Rotterdam, rather than the number of "allochthonous" which is more familiar in the Netherlands. The latter figure includes anyone who is either born in or who has at least one parent born in a CEE country. This includes long-term CEE residents in the Rotterdam (for instance, CEE family migrants who once arrived in the Netherlands) and also children of mixed couples. By using data about CEE nationals, we intent to focus on recently arrived CEE migrants in Rotterdam (partly migrant workers, but also students and recently arrived family migrants). The number of CEE nationals is somewhat lower than the number of CEE residents in Rotterdam measured by "country of birth". These figures include nationals from Bulgaria, Romania, and Croatia in all years, although these countries joined the EU only in 2007 and 2014 respectively.
} 
However, the actual number of CEE migrants residing in the city of Rotterdam is higher than the number of those registered in the municipal population registrations. As previous research shows, many CEE migrants do not register with the local authorities. In fact, according to Dutch immigration legislation, foreigners are only obliged to register when they stay (or intent to stay) more than 4 months. In a survey of 150 labour migrants from Poland, Romania and Bulgaria in Rotterdam, only one third of the respondents reported they had actually registered with the municipality (Snel et al. 2011a, b: 18). This corresponds with later research of Van der Heijden et al. (2013). Using statistical estimation techniques and various sources of administrative data, they estimate that $340,000 \mathrm{CEE}$ residents were actually present in the Netherlands in 2010, three times more than the number of registered CEE residents at the time. Applying this ratio to the number of registered CEE residents in the city, the Rotterdam authorities estimate that there are between 30,000 and 50,000 CEE residents in the city (Municipality Rotterdam 2015). ${ }^{3}$

For the time being, we can conclude that we do not have exact figures about the amount of CEE residents in Rotterdam. We do know that a small majority (53\%) of the registered CEE residents in Rotterdam is female. ${ }^{4}$ This shows that the migration from Central and Eastern Europe to Rotterdam (and to Western Europe in general) is in line with the more general trend towards a "feminization" of international migration (Castles et al. 2014). We also know that the registered CEE residents in Rotterdam are concentrated in specific Rotterdam districts such as Delfshaven in the northern part and Feijenoord and Charlois, located in the southern part of the city. These districts are known as places with relatively many private landlords renting accommodation. Migrant workers are often in need of immediate lodging, and as public housing has long waiting queues, private rented dwellings are attractive for them, even when they are overcrowded (migrant workers often have to share a bedroom), poorly maintained or costly (De Leeuw et al. 2016; Snel et al. 2011a, b: 30).

Another relevant issue concerns the return intentions of CEE labour migrants. Although CEE migrant workers are often perceived and treated as typical temporary or circular migrants, a growing number of them intends to stay longer or even permanently in the Netherlands. When asked how long they intend to stay in the Netherlands, only one in five of the Rotterdam respondents indicated they wanted to stay in the Netherlands for 2 years at most (Snel et al. 2011a, b: 33). About one third of the respondents wanted to stay for 5 years or longer (including permanently) and about $40 \%$ of them said they "don't know" how long they will stay. The latter answer, also called 'intentional unpredictability', is said to be typical for many CEE migrants in Western Europe (Drinkwater et al. 2010). In Rotterdam, about one in three of the Polish and Romanian respondents and not less than $45 \%$ of the Bulgarian respondents said they do not know whether they will stay in the Netherlands. This illustrates the uncertain life conditions and prospects of many CEE migrant workers

\footnotetext{
${ }^{3}$ Uitvoeringsagenda 2015-2018, pp. 6.

${ }^{4}$ Rapportage Monitor EU-arbeidsmigratie 2014, pp. 10.
} 
in Rotterdam. Next to this, there are growing numbers of long-term residencies in Rotterdam. The municipal registration data shows that $17 \%$ of all registered CEE residents in Rotterdam had resided in the city between 5 and 10 years, while $15 \%$ even lived in Rotterdam 10 years or longer (Municipality Rotterdam 2013: 14).

This more (semi-)permanent settlement in Rotterdam implies in most cases the settlement of more families and children. As recent research shows, the total number of children, (aged 0 until 17 years) from EU residents residing and registered in Rotterdam, almost doubled between 2010 and 2014 (from 1639 to 2804 children) (Seidler et al. 2015, 30). Although the share of CEE children of all minors in Rotterdam (about 2\%) is not that large, this share may be higher in some Rotterdam districts with many CEE migrants. Particularly in these districts, schools complain about strong fluctuations in the presence of children from CEE migrants. As their parents are highly mobile, the children show up and unexpectedly disappear again from schools. As a participant in an expert meeting mentioned: "I have to deal with extreme movements within one school year. I have 250 movements annually, which are 250 pupils who flow in and out (..). In some classes this is 70 per cent". ${ }^{5}$ Another issue often mentioned in Rotterdam policy circles relates to families and children 'out of sight': migrant children in Rotterdam who are not registered and also do not attend school. One of the reasons for this commotion came from reports that Romanian and Bulgarian juveniles in Rotterdam would not attend school, but are instead involved in delinquent activities. However, when the Rotterdam City Council then asked for information about the number of unregistered children from CEE parents in Rotterdam, ${ }^{6}$ researchers found "no strong indications" that Rotterdam has large numbers of unregistered children not attending school. ${ }^{7}$

To understand the labour market position of CEE residents in Rotterdam we have to rely on relatively small surveys among CEE labour migrants. The first survey gives information about 400 Polish workers in two Rotterdam districts (Tarwewijk and Oud-Mathenesse). About half of the respondents work in horticulture or food production, but also in construction work. The majority of the respondents earned about the Dutch legal minimum wage. Despite this low wage level (at least for Dutch standards), only few respondents were discontent with their present work (Municipality Rotterdam 2008a: 10-17). Some years later, Snel et al. (2011a, b: 20-23) surveyed 150 Polish, Romanian and Bulgarian migrant workers in Rotterdam. Something peculiar in the sample of Bulgarians is that many of them have a Turkish ethnic background. Although this gives them the opportunity of receiving support from Dutch-Turkish residents in Rotterdam, for instance,

\footnotetext{
${ }^{5}$ Cited in: Van Ostaijen et al. (2015), Social consequences of CEE migration. Country report of the Netherlands. Internal report of the Imagination project, pp. 24.

${ }^{6} \mathrm{http}: / / \mathrm{www} . v v d r o t t e r d a m . n 1 / \mathrm{blog} /-/$ moelanders-een-probleem-of-niet/1389

${ }^{7}$ The researchers found some unregistered children who do attend school. When asked why the parents did not register themselves with the municipality, the researcher found that is sometimes due to lack of knowledge, but also to private landlords who prohibit their tenants to register, for instance when too many people live in overcrowded houses (Seidler et al. 2015).
} 
obtaining jobs from Turkish employers, the Bulgarians in the sample have the lowest socio-economic profile. Half of the Bulgarian respondents work in informal work arrangements, often with a Turkish employer. Most Polish respondents are employed by temporary employment agencies (in Dutch: 'uitzendbureaus'). Although many respondents are well-educated, about half of them work in either unskilled manual jobs or in (also mostly unskilled) agricultural work. One in three respondents (half of all Polish respondents) say they work below their educational level. The salaries are generally low: around and sometimes even below the legal minimum wage level in the Netherlands. On the other hand, about one in ten respondents appear to have higher qualified professional occupations. They work as IT-specialists, scientific researchers, dentist or as an architect. This, again, illustrates the diversity among CEE labour migrants in Rotterdam and it shows the diversity of this migrant population in terms of their intention to stay, their labour market position and their skill level. Now, we will study how Rotterdam local political and policy actors responded to this issue.

\subsection{Local Politics and Policies Regarding CEE Migrants in Rotterdam}

The year 2002 was a crucial moment in the history of local politics in Rotterdam. Since World War II, Rotterdam was governed by the Dutch Labour Party (PvdA), but from the year 2000 onwards there were growing complaints about crime and nuisance in the city and the (alleged) multicultural tolerance of the Rotterdam city administration. This resulted in the sudden rise of the politician Pim Fortuyn. When his political party 'Liveable Rotterdam' won the local elections it became the main force in the new city administration (2002-2006). This was a turning point in Rotterdam's local politics and administrative culture. Some even termed it a 'regime change' implying that the central issues of Liveable Rotterdam - a strong focus on crime and safety issues and a critical stance on immigration and multiculturalism would remain, even if the party was not in the city administration (Tops 2007). This new 'regime' focus implied different political and policy reactions, also in the years when Liveable Rotterdam was not represented in the City Board (this was the case from 2006 to 2014).

Figure 8.2 shows that the issue of CEE migration was often discussed in the Rotterdam local politics. The figure shows how often specific Dutch words related to this migrant category (terms like 'MOE-land'8 and 'labour migration') were used in official Rotterdam City Council documents throughout the period 2000-2014. ${ }^{9}$

\footnotetext{
${ }^{8}$ Literally "CEE land". "MOE" can be translated as 'Middle and Eastern Europe' ("Midden en Oost Europa").

${ }^{9} \mathrm{http} / / / \mathrm{www}$. ris.rotterdam.nl, searched on 'MOE-land' and 'arbeidsmigratie' between the period 01-01-2000 and 01-01-2015 in 'all documents'.
} 


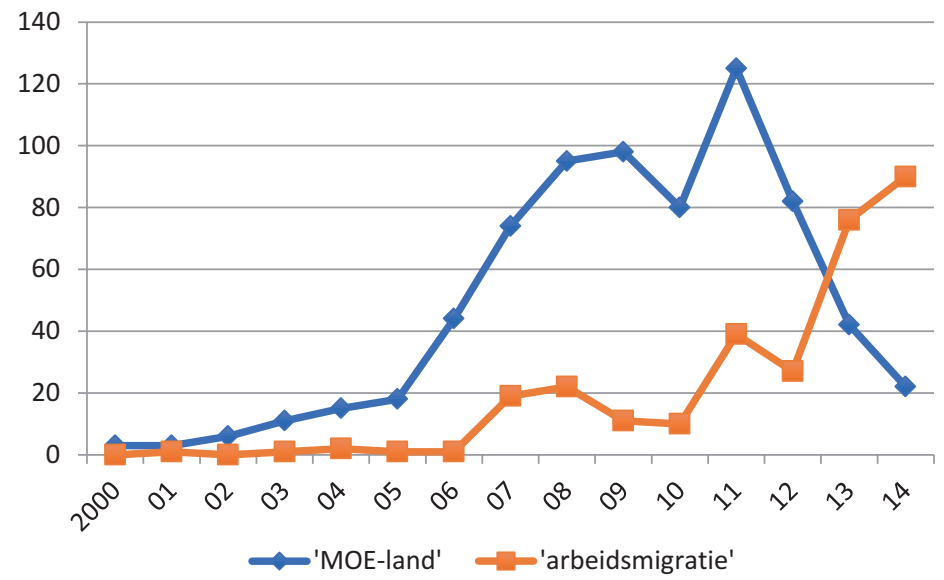

Fig. 8.2 'MOE-land' and 'labour migration' in Rotterdam City Council documents (2000-2014). (Source: Municipality of Rotterdam (Rotterdam City Council))

Figure 8.2 shows that the political attention for 'CEE migrants' (in Dutch: 'MOE-landers') and, as it was termed afterwards: 'labour migration' (in Dutch: 'arbeidsmigratie') started around 2005 and became a more prominent topic in 2007. The year 2007 was also the moment when the cities of Rotterdam and The Hague jointly organized a so-called 'Poles summit', ${ }^{10}$ to which the Labour Party (PvdA) aldermen in both cities played a crucial role. The summit was meant to raise public awareness and attention from national policy makers for what was framed as the local consequences of the European policy of free movement. Forty-two municipalities and two national ministers attended the summit. Also after this occasion, Rotterdam continued to 'knock at the door of the national government' to ask for policy measures, since they realised 'we cannot do things on our own' (Municipality Rotterdam 2008a: 27). Although the 'Poles Summit' did not deliver direct policy results, it was an important moment for the agenda setting to raise attention to this issue. As the Rotterdam alderman Karakus (PvdA) reflects on how he aimed to raise attention to the issue of overcrowded housing:

Along the way I went to all chairmen of all political parties in the national Parliament and described the problem. [...] I've shown how many people we encountered in those houses, which scared people. Then the government was awakened by the Parliament: you have to do something about this. ${ }^{11}$

\footnotetext{
${ }^{10}$ The term of this summit does not refer to the fact that only Polish people were present or that all issues on the agenda were related to Polish 'migrants'. This term was used and is a reflection of the public opinion regarding CEE migration in the Netherlands is very much focused on Polish people.

${ }^{11}$ Interview with (former) Rotterdam alderman Hamit Karakus.
} 
In the same period, The Hague's alderman Norder (also PvdA) referred to this issue as "a tsunami of CEE migrants", while his Rotterdam counterpart Karakus said it was 'mopping the floor with the tap wide open' to combat the local consequences of CEE migration. Karakus particularly demanded legislation to combat illegal landlords, so he could 'hit them in their kidneys'. It strongly marked this period and the local efforts for national awareness and attention towards this issue.

A second peak in the political attention for CEE migrants in Rotterdam was in 2011. This was on the one hand related to various local policies (on housing, labour market issues and nuisance) that were debated in the City Council. On the other hand, the attention-raising period succeeded, which resulted in a national Parliamentary Commission (Temporary Parliamentary Commission 2011) 'Lessons concerning recent labour migration' which examined the social and economic consequences of CEE migration to the Netherlands. This commission placed the issues of Rotterdam on the national agenda. After that, the term "MOE-land" became gradually replaced by the politically more generative term 'EU labour migrants' ${ }^{12}$ This new term also included other EU labour migrants, such as migrants from Southern European countries.

When looking at the Rotterdam policy discussions regarding CEE migrants, we distinguish four different problem definitions. Firstly, there were major concerns regarding the housing situation of CEE migrants in relation to (alleged) nuisance in the 'old neighbourhoods' of Rotterdam. CEE labour migrants generally had to rely on private landlords as far as they were not housed by their employers and were unable to deal with the waiting lists for public housing. In practice, many CEE migrants ended up in overcrowded, privately rented houses in deprived urban areas, particularly in the southern part of the city (De Leeuw et al. 2016). Already at the 'Poles Summit', the Rotterdam spokesmen underlined the problems of illegal tenants, overcrowded dwellings and inconveniences in public spaces in these vulnerable districts (Municipality Rotterdam 2008b, 2011, 2012). As a more recent policy document states:

[...] we attack (residential) nuisance. And do not accept that too many people live in too small houses. Where we want to prevent that inhabitants live in large scale and badly maintained houses with fire- and safety risks. And above all: where we will prevent the heavy burden on neighbourhoods which are already under social and economic pressure. (Municipality Rotterdam 2015: 2)

The Rotterdam administration attempted to tackle this issue in two different ways. On the one hand, Rotterdam demanded more support, better legislation and effective policy instruments from the national government. This resulted in a wide range of national policies, laws and legislation addressing issues raised by Rotterdam and other cities. For example Rotterdam raised the issue of the 'uneven distribution' of low-income households in 'vulnerable' neighbourhoods. This resulted that the National Parliament accepted a new law, the 'Act Exceptional Measures for Urban

\footnotetext{
${ }^{12}$ Mainly because of resistance felt from CEE migrants groups with the word 'MOE-landers'. Partly because the Dutch word 'moe' also means 'tired', which was perceived as stigmatising.
} 
Problems' (also known as the 'Rotterdam Act'), This Act enabled Rotterdam from 2006 onwards to develop a selective settlement policy for vulnerable districts. ${ }^{13}$ More specifically, this instrument enabled the municipality to refuse non-working households to settle in specific Rotterdam districts, at least when they arrive from outside Rotterdam. Next to this, the Minister of Housing, Neighbourhoods and Integration (WWI) declared that specific urban neighbourhoods are disproportionally under pressure (Letter to Parliament 2010), which directly addressed the 'problem definition' of Rotterdam. An Intention Declaration was developed to enlarge the instruments of local governments in an 'Approach to attack slum landlords' (Letter to Parliament 2012). And above all, the Rotterdam Act was revised in 2013 (Rotterdam Act II) as a direct response to new urban concerns about irregular landlords and disturbances in public spaces in these districts. These examples show how Rotterdam's problem definitions gained national acknowledgment and how they were an important incentive for national legislation and policy instruments (Municipality Rotterdam 2008b, 2015).

On the other hand, Rotterdam developed new local policies related to 'irregular' housing and related nuisance caused in already 'vulnerable districts' (Municipality Rotterdam 2007, 2015). For this 'top priority', Rotterdam developed several policies to intervene in private housing situations. For instance, the city started to attack illegal housing with the so-called 'Alijda Approach' (Municipality Rotterdam 2007). This approach introduced a quota to forbid 'more than two temporary labour migrants' per dwelling in certain 'vulnerable' neighbourhoods. To combat irregular slum landlords, the city developed a 'three strikes you're out'-policy, implying that house owners lost their Housing Permit if they were penalized for three deviancies. As the former Rotterdam alderman Karakus noted:

We had a black list of housing owners who putted too many people in one place. And we finished that list. 'Three strikes you're out' was a theme we took very serious. Later this also has been accepted by the Parliament.

This policy approach enabled Rotterdam to intervene more directly in the private sphere and to solve the issues related to housing (Municipality Rotterdam 2008b, 2015).

A second major policy concern of the Rotterdam authorities related to CEE migration, next to housing issues, concerned the exploitation of workers by irregular employers and temporary employment agencies. According to the previous mentioned Parliamentary Commission LURA (2011: 52), there were at least 5000 irregular temporary employment agencies active in the Netherlands, employing about 100,000 (foreign) workers. These irregular agencies are seen as a major

\footnotetext{
${ }^{13}$ Rotterdam requires from new residents in certain vulnerable that they have a so-called settlement permit ('huisvestigingsvergunning'). This permit is only issued either when the household in question has an income from work (or from study allowances or pensions) or when the household resides in the city for 6 years or longer. This measure was not explicitly aimed at migrants, let alone CEE migrants, but was intended to reduce the number of 'vulnerable' residents in these already 'vulnerable' Rotterdam districts (Hochstenbach et al. 2015).
} 
problem, not only because of the exploitation of foreign workers, but also because native (and previous migrant) workers are unable to compete with this cheap foreign labour. Already at the 'Poles Summit' in 2007, Rotterdam demanded measures from the national government to counteract irregular temporary agencies. Although regulating temporary employment agencies is not really a task of local administrations, the municipalities of Rotterdam and The Hague agreed a Covenant with employment agencies to mediate between the demands of employers and potential employees (Municipality of Rotterdam 2007, 2008b, 2011, 2012). Some years later, Rotterdam participated in the 'Rotterdam Approach Malafide Employment Agencies' (RAMU) that agreed on intensified controls and regulations to counteract malafide agencies together with the national interest organisation of temporary employment agencies (ABU). This is an example of how the Rotterdam city Board tried to counteract irregularities regarding labour market issues of CEE migrants. Unfortunately most of the issues were outside the legal scope of municipalities, or as one of the civil servants indicated it afterwards: "With the Minister, the Inspection and the organisation of temporary employment agencies $(A B U)$ we made a plan, as we said quite tough in those days, to 'get 100 irregular temporary agencies of the market'. But that is complicated, since as a municipality we have a very limited role, there are others active in this".

A third policy concern focussed on the issue of non-registration of CEE migrants. Following Dutch immigration rules, foreigners are only obliged to register with the local authorities if they (intend to) stay for 4 months or longer in the Netherlands, resulting that many migrants stay out of sight. Research indicated that one third of the respondents was not registered with the municipality (Snel et al. 2010: 18), Rotterdam demanded better legislation to keep residents 'in sight'. This then evolved into the new law, Register New Inhabitants (RNI) (see: van Ostaijen et al. 2015). This law made it possible to cluster data of different public authorities to make resident addresses easier visible. The new law was introduced by the Ministry of Internal Affairs in response to demands of Rotterdam (and The Hague). Or as one Rotterdam civil servant reflects on this: "all the time that I'm involved, registration is an issue. And it stays an issue. [...] Therefore, our demand is to make this a national approach". As such, despite these new laws and legislation, improvements are still needed.

A final policy problem is related to Dutch language courses for 'CEE migrants'. As EU citizens, CEE migrants are not obliged to take any kind of language or integration courses. Therefore, in the beginning (2007-2012), Rotterdam offered CEE migrants free 'integration courses'. Nowadays, CEE migrants can still take language courses, with the prerequisite that they need to be registered at the municipal registration. Mostly, there is a reduced fee with specific attention to certain target groups (language courses for women, integration courses, illiteracy). There was nevertheless a stable focus on language and integration in the political and policy attention in Rotterdam (Municipality Rotterdam 2013). 


\subsection{CEE-Residents and Disorder in Rotterdam Districts: A 'Fact Check'}

A major issue in the public and political debate about CEE migrants in Rotterdam relates to nuisance and disorder in those districts where many migrants settle. Since there are long waiting queues for public housing, many CEE-labour migrants have to rely on privately rented houses. Particularly, in the southern part of the city, there are various districts with a relatively large stock of privately rented housing that attract newly arrived CEE migrants. These are relatively deprived areas, with an old and sometimes dilapidated housing stock, largely populated by residents with a migrant background, and with more than average unemployment and poverty rates. The influx of CEE migrant workers would put these already vulnerable Rotterdam districts under even more stress. A recurrent issue in Rotterdam policy and political debates is how the influx of CEE migrant workers causes inconveniences in these areas: from overcrowded houses, which cause shortage of parking facilities to public nuisance, including noise and public drinking.

Using statistical data from the Rotterdam Safety Monitor (2007-2013), we examine whether there is any empirical ground for the alleged association between the influx of CEE nationals in Rotterdam districts on the one hand and increased numbers of (reported) incidences of nuisance and the perceptions of residents about nuisance on the other hand. In our analysis we use two different indicators to measure nuisance in Rotterdam districts: the number of reported incidences of nuisance per 1000 residents (Table 8.1) and the share of respondents that say there is "often" nuisance in their own neighbourhood (Table 8.2). The first indicator can be regarded as a more or less objective measure of nuisance, the latter is the subjective perception of nuisance by district residents.

Starting with Table 8.1, model 1 shows that the number of registered incidences of nuisance slightly decreases over the years. Most years in model 1 show negative values, indicating less registered incidences of nuisance compared to the reference year (2007), although none of the indicators are significant. In model 2 we included the share of CEE nationals in the district population as a new factor in the analysis. It appears to have a significant positive effect on the number of registered incidences in the district: the more CEE nationals in the district, the more incidences. However, this apparent effect disappears again when we include several other neighbourhood characteristics in the analysis. Model 3 shows significant positive effects of various neighbourhood characteristics on the occurrence of incidences: the more privately rented housing, the more juveniles, the more low income households and a 'functional mix' (that is: housing, shops and other businesses) in the district, the more incidences of nuisance. Moreover, there is a rather surprising negative effect of the share of non-Western residents in the district: the more non-Western residents, the less incidences. The reason for this negative effect is not quite clear. When we take these effects into account, there is no negative effect of the presence of CEEnationals on the number of incidences anymore. 


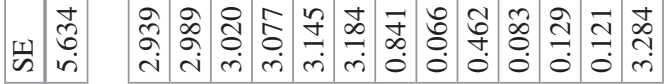

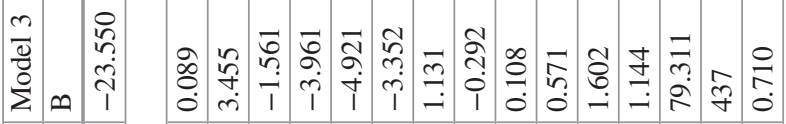

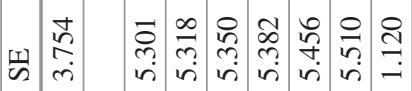

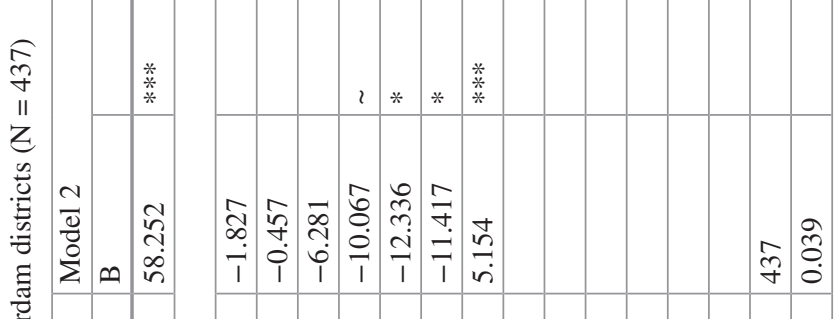

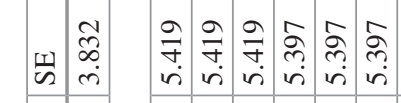

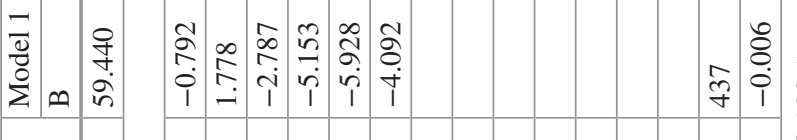

当

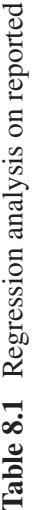

苦

菜

भิ

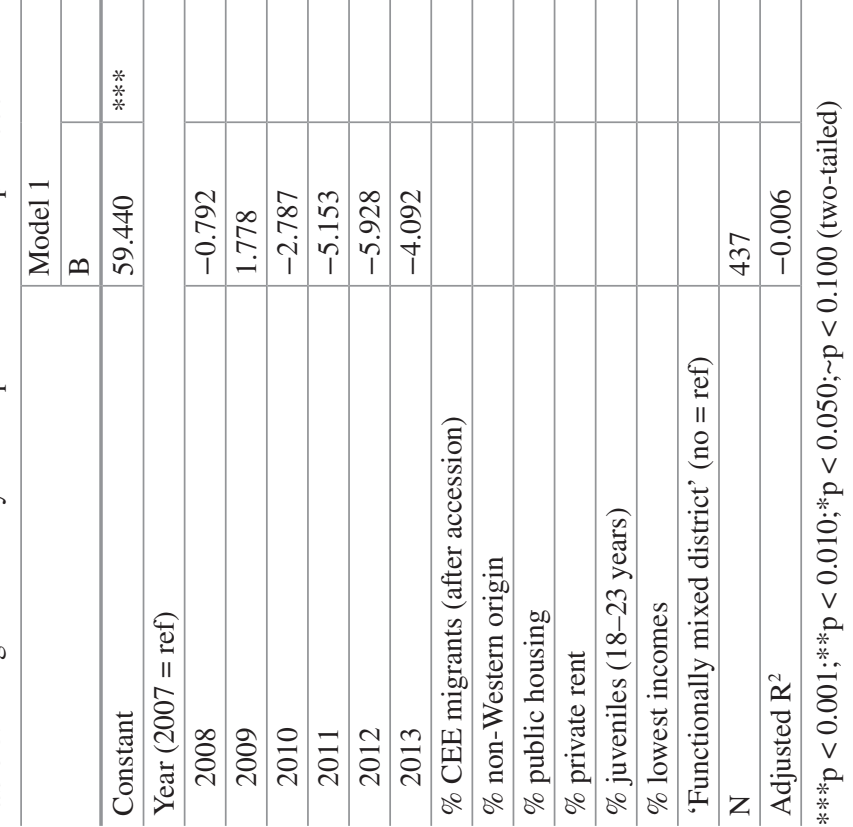


Table 8.2 Regression analysis on \% of residents that say there is "often" nuisance in their own district $(\mathrm{N}=312)$

\begin{tabular}{|c|c|c|c|c|c|c|c|c|c|}
\hline & \multicolumn{3}{|c|}{ Model 1} & \multicolumn{3}{|c|}{ Model 2} & \multicolumn{3}{|c|}{ Model 3} \\
\hline & B & & SE & B & & SE & B & & SE \\
\hline Constant & 2.706 & $* * *$ & 0.562 & 2.284 & $* * *$ & 0.495 & -5.433 & $* * *$ & 1.068 \\
\hline \multicolumn{10}{|l|}{ Year $(2007=$ ref $)$} \\
\hline 2008 & 5.352 & $* * *$ & 0.795 & 4.984 & $* * *$ & 0.698 & 5.143 & $* * *$ & 0.515 \\
\hline 2009 & 7.009 & $* * *$ & 0.795 & 6.215 & $* * *$ & 0.701 & 6.643 & $* * *$ & 0.527 \\
\hline 2011 & 7.568 & $* * *$ & 0.792 & 5.822 & $* * *$ & 0.717 & 6.620 & $* * *$ & 0.551 \\
\hline 2013 & 7.473 & $* * *$ & 0.792 & 4.870 & $* * *$ & 0.744 & 6.017 & $* * *$ & 0.578 \\
\hline $\begin{array}{l}\text { \% CEE migrants (after } \\
\text { accession) }\end{array}$ & & & & 1.831 & $* * *$ & 0.189 & 1.003 & $* * *$ & 0.180 \\
\hline$\%$ non-Western origin & & & & & & & 0.079 & $* * *$ & 0.013 \\
\hline$\%$ public housing & & & & & & & -0.002 & & 0.017 \\
\hline$\%$ private rent & & & & & & & 0.017 & & 0.026 \\
\hline$\%$ juveniles (18-23 years) & & & & & & & 0.026 & & 0.095 \\
\hline$\%$ lowest incomes & & & & & & & 0.094 & $* * *$ & 0.024 \\
\hline $\begin{array}{l}\text { 'Functioneel gemengde wijk' } \\
\text { (no =ref) }\end{array}$ & & & & & & & -0.875 & & 0.677 \\
\hline $\mathrm{N}$ & & 312 & & 312 & & & & & 312 \\
\hline Adjusted $\mathrm{R}^{2}$ & & 0.287 & & 0.453 & & & & & 0.708 \\
\hline
\end{tabular}

\section{Technical explanation}

Dependent variables: reported incidences of nuisance per 1000 residents of Rotterdam neighbourhoods (Table 8.1 ) and share of respondents (15 years or older) per neighbourhood that say there is "often" nuisance in the public sphere in their own neighbourhood (Table 8.2).

Control variables: (1) CEE migrants as \% of the total population per district (note that these data relate to foreign-born individuals, including second generation migrants, but only those who live in Rotterdam since the EU Enlargement in 2004); (2) all individuals with non-Western origin, including second generation, as a \% of the total population per district (thus: anyone born or with at least one parent born in a non-Western country); (3) public housing as \% of the total housing stock per district; (4) private rented houses as \% of the total housing stock per district; (5) juveniles (18-23 years) as \% of the total population per district; (6) low-income households as \% of all households per district; (7) whether or not a district is classified as "functional mixed", that is with both housing, shops and other industries or activities.

After residue analysis, two Rotterdam districts (Wielewaal and Pendrecht) are removed from the analyses.

Source: http://rotterdam.buurtmonitor.nl/jive; https://wijkprofiel.rotterdam.nl/ $* * * \mathrm{p}<0.001 ; * * \mathrm{p}<0.010 ; * \mathrm{p}<0.050 ; \sim \mathrm{p}<0.100$ (two-tailed)

Similarly, Table 8.2 examines the possible association between the presence of CEE-nationals in Rotterdam districts and the residents' perception of nuisance in the district. A first remarkable outcome is that values in model 1 are significant and positive. This implies that, compared to the situation in 2007, in later years more respondents think there is much nuisance in the district - although we just saw that the number of registered incidences decreased over the years. Model 2, again, shows a positive effect of the share of CEE migrants in the local population on the perception of nuisance: the more CEE-nationals in the district, the more residents perceive nuisance in the neighbourhood. Contrary to the analysis in Table 8.1, this effect 
remains when we include the other neighbourhood characteristics into the analyses (model 3). Although this model also shows significant effects of the size of minority populations and the share of low-income households on the perceptions of nuisance, the presence of CEE migrants still has a strong and positive effect on the perceptions of nuisance.

In short, our analyses point out a rather remarkable difference between more objective measures of the occurrence of nuisance and the residents' subjective perceptions of nuisance. Although we could not find an independent effect of the presence of CEE migrants on the number of registered incidences of nuisance, ${ }^{14}$ the presence of $\mathrm{CEE}$ migrants has an effect on resident perceptions of nuisance: the more CEE migrants live in a district, the more residents perceive nuisance in their neighbourhood - although we could not find a direct association between the presence of CEE migrants and registered practices of nuisance.

\subsection{Discussion}

How does a superdiverse city like Rotterdam react to a new, substantial form of migration? Rotterdam has always been a city of immigrants. Its harbour and industries also attracted migrant workers in the past, both internal migrants and foreign workers. Since the EU-enlargements in 2004 and 2007, Rotterdam, like many other European cities, is confronted with substantial numbers of CEE migrant workers and their families. In this chapter we described what this new migrant category means for the city, and particularly how Rotterdam, by means of its political debate and local policies, reacted to it.

On the one hand, we emphasized that although CEE migrants are generally perceived as a homogeneous category ('de MOE-landers') in the Dutch media and politics, in reality it is a rather diverse group. Not only did they arrive from a variety of CEE-countries, they are also diverse in other aspects. CEE-migrant workers are not only young males and females, looking for low-skilled and temporary jobs in Rotterdam industries and in the horticultural sector of Rotterdam's neighbouring city Westland. Different from previous periods of labour migration, CEE migrants are often quite well educated. Although many of them indeed work in low-qualified jobs (a clear example of de-qualification after migration), some CEE migrants were found in highly qualified positions. Whereas many migrant workers started as typical circular migrants, quite a few of them settled meanwhile permanently with families and children. In other words, CEE migrants in Rotterdam are far more diverse than popular images of temporary workers at 'the bottom of the urban labour market' suggest. As such, this new migrant category contributes to the already existing 'superdiversity' in Rotterdam as an immigrant city (Vertovec 2007).

\footnotetext{
${ }^{14}$ The initial effect was 'explained away' by the other neighbourhood characteristics.
} 
To understand Rotterdam's policy reaction to the influx of CEE migrant workers, one should keep in mind the specific political climate in Rotterdam in the early 2000s. After the rise of political party Liveable Rotterdam, there was a growing discontent about the city's multicultural policies of the 1990s. A stricter approach on immigration, multiculturalism and security issues also influenced other parties in Rotterdam local politics, including the Labour Party (PvdA) that came back in the City Board from 2006 to 2014 (van Ostaijen and Scholten 2014). This political climate also characterised Rotterdam's rather hesitant or even reluctant policy approach regarding CEE migrants in the city. Our main argument in this chapter is that Rotterdam problem definitions and policy efforts related to CEE migrants do not reflect the actual diversity within this migrant category. Our analysis rather displays Rotterdam as a case of complexity reduction with a specific focus of local policies on temporary, mainly young, male and low-skilled migrants and on the (alleged) problems associated with these categories (such as exploitation by irregular temporary employment agencies, uncertain housing conditions and nuisance caused by drinking in public spaces), while neglecting the fact that other CEE migrants and their families live in far more stable conditions.

Indicative for this complexity reduction was the moral panic which can be illustrated by two examples. First there were 'stories' about 'invisible children': children of CEE migrant families, who seemed unregistered and not attending school, but allegedly engaged in delinquent activities. A study commissioned by the Rotterdam authorities did not find indications that these phenomena exist in Rotterdam. Secondly, there is also a recurrent narrative in Rotterdam's political and policy debates about the nuisance of CEE migrants in the city's already 'vulnerable' districts. This 'story' states that young, male CEE migrant workers are housed in privately rented, often overcrowded accommodations, which are overrepresented in certain areas in the south of Rotterdam with a vulnerable population (many migrant families, substantial unemployment, social benefit claiming and poverty, many disorderly juveniles). The story continues with the argument that CEE migrants especially have limited privacy in these overcrowded dwellings, which causes public drinking and nuisance in the streets since there is a certain tradition of collective drinking in public spaces among Polish males (Garapich 2011). In this chapter, we examined this story by using municipal data, and looked whether there is an empirical association between the share of CEE nationals in Rotterdam districts and reported incidences of nuisance in the same areas. Our analysis did not confirm this association. The number of registered incidences of nuisance in Rotterdam districts is related to other neighbourhood characteristics such as the share of juveniles and non-Western immigrants in the neighbourhood population and the share of privately rented dwellings, rather than with the share of CEE nationals in the district. We did, however, find that people's perceptions of nuisance in the neighbourhood were associated with the share of CEE nationals. The more CEE nationals in a Rotterdam district, the more residents perceive nuisance as a problem of the area. 
Both illustrations of this 'moral panic' are indicative of the specific complexity reduction from the side of Rotterdam authorities. On the one hand, the EU perspective reduces the complex East-West migration picture by mainly underlining the positive consequences of this new form of mobility flow. On the other hand, local authorities also reduce the complexity of CEE migration by focusing their attention mainly on social problems (allegedly) caused by young, male, generally lowskilled, temporary migrant workers. These public and political perceptions tend to simplify EU migration in terms of specific 'types' of migrants rather than acknowledging and capturing the differentiated nature of contemporary CEE migration to the Netherlands, and to Rotterdam. In our view, this complexity reduction is counterproductive, not only because it contributes to the contested character of CEE migration in the Netherlands, but also because it hinders the quest for effective policy solutions. For instance, local policies should not only find temporary housing facilities for temporary migrant workers, but also help migrants and their families, who want to stay in the Netherlands for longer periods of time, to find better accommodations. Local policies should not only fight the exploitation of migrant workers by irregular temporary employment agencies, but also help migrants to find employment on par with their educational level. Local policies should not only try to reduce nuisance in Rotterdam districts caused by young male migrants, who live in overcrowded houses without any room for privacy, but should also support migrants and their families to find proper housing facilities.

Concluding, the focus on Rotterdam displays the specificity in the Rotterdam approach towards CEE migrants, considering it as a coherent category or group. But the homogenous characterisations (which can be derived from concepts such as 'MOE-landers', 'Poles-summit' and 'Poland working groups') contrasts strongly with the heterogeneity that we showed in terms of nationality, ethnicity, socialeconomic status and temporality of stay. Our chapter shows this diversity and the efforts of Rotterdam to reduce this complexity, while one could argue that its heterogeneous character demands a more diversified approach.

As such this chapter reveals the 'other story' of a more reluctant superdiverse city, like Rotterdam. Our analysis shows the complexity reduction of a city coming to terms with its superdiverse character as a city of migration. But as a reluctant city, Rotterdam may not be an extreme or outlier case. There are multiple cities in Europe, and elsewhere in the world, that probably have more in common with such reluctance than with the cosmopolitan approach of more 'happy' superdiverse cities like London, Amsterdam and New York (Foner et al. 2014). As such, our chapter shows that not Rotterdam but these 'happy' superdiverse cities could be seen as outlier cases, which outlines the significance of cities like Rotterdam in the analysis of superdiversity. 


\section{References}

Castles, S., de Haas, H., \& Miller, M. (2014). The Age of Migration. International population movements in the modern world. London: Palgrave Macmillan.

Cornelius, W. A., Martin, P. L., \& Hollifield, J. F. (2004). Controlling immigration: A global perspective. Stanford: Stanford University Press.

De Leeuw, T., van Summeren, A., \& Snel, E. (2016). Grijs wonen' in Rotterdam. Een onderzoek naar de kansen en beperkingen van huurders en verhuurders aan de onderkant van de particuliere woningmarkt. Rotterdam: Kenniswerkplaats Leefbare Wijken.

Drinkwater, S., Eade, J., \& Garapich, M. (2010). What's behind the figures? An investigation into recent Polish migration to the UK. In R. Black, G. Engbersen, M. Okolski, \& C. Pantiru (Eds.), A continent moving West? EU enlargement and labour migration from Central and Eastern Europe (pp. 73-88). Amsterdam: Amsterdam University Press.

Engbersen, G., Leerkes, A., Grabowska-Lusinska, I., Snel, E., \& Burgers, J. (2013). On the differential attachments of migrants from Central and Eastern Europe: A typology of labour migration. Journal of Ethnic and Migration Studies, 39(6), 959-981.

Foner, N., Rath, J., Duijvendak, J. W., \& van Reekum, R. (2014). New York and Amsterdam: Immigration and the new urban landscape. New York: NYU Press.

Garapich. (2011). Of alcohol and men: Survival, masculinities, and anti-institutionalism of homeless people in a global city. Studia Migracyjne-Przeglad Polonijny 1, 309-331

Hochstenbach, C., Uitermark, J., \& van Gent, W. (2015). Evaluatie effecten Wet bijzondere maatregelen grootstedelijke problematiek ("Rotterdamwet") in Rotterdam. Amsterdam: UVA (AISSR).

Letter to Parliament. (2010). Plan van Aanpak huisvesting en inburgering van arbeidsmigranten uit Midden-en Oost- Europa. 25-06-2010.

Letter to Parliament. (2012). Vrij verkeer van werknemers uit de nieuwe EU lidstaten. Inzake Nationale verklaring huisvesting. 29407: 146.

Municipality Rotterdam. (2007). Migratie in goede banen. Midden en Oost-Europeanen in Rotterdam. Rotterdam.

Municipality Rotterdam. (2008a). Polen in Rotterdam (Verkennend onderzoek van de leef- en werksituatie van de (toekomst)plannen van Polen in Rotterdam). Rotterdam: Bestuursdienst.

Municipality Rotterdam. (2008b). Monitor Midden en Oost-Europeanen. Rotterdam.

Municipality Rotterdam. (2011). Monitor EU arbeidsmigranten. Rotterdam.

Municipality Rotterdam. (2012). Brief 'Uitbreiding Rotterdamwet t.b.v. kwaliteitssprong Zuid'. 01-05-2012.

Municipality Rotterdam. (2013). De uitvoeringsagenda 2013-2014 EU arbeidsmigratie. Rotterdam. Municipality Rotterdam. (2015). De uitvoeringsagenda 2015-2018 EU arbeidsmigratie. Rotterdam.

Muus, P. (2004). The Netherlands: A pragmatic approach to economic needs and humanitarian considerations. In W. A. Cornelius, P. Martin, \& J. F. Hollifield (Eds.), Controlling immigration: A global perspective. Stanford: Stanford University Press.

Seidler, Y., Weltevrede, A. M., de Boom, J., \& Leerkes, A. (2015). Ongeregistreerde' kinderen met een EU-achtergrond in Rotterdam. In Een inventarisatie van de omvang en achtergronden van kinderen en jongeren met een EU-achtergrond die niet voorkomen in de Basisregistratie Personen van Rotterdam. Rotterdam: Risbo.

Sert, D. (2014). Mapping and analysis of types of migrants from CEE countries. Comparative report. IMAGINATION working paper.

Snel, E., Burgers, J., Engbersen, G., Ilies, M., Van der Meij, R., \& Rusinovic, K. (2010). Arbeidsmigranten in Rotterdam. Rotterdam: NICIS/EUR.

Snel, E., Van de Pol, S., Burgers, J., Engbersen, G., Ilies, M., Van der Meij, R., \& Rusinovic, K. (2011a). Arbeidsmigranten in Den Haag. Rotterdam: NICIS/EUR. 
Snel, E., Engbersen, G., Ilies, M., van der Meij, R., \& Hamberg, J. (2011b). De schaduwzijden van de nieuwe arbeidsmigratie. Dakloosheid en overlast van Midden- en Oost-Europese arbeidsmigranten in Den Haag. Rotterdam: EUR.

Temporary Parliamentary Commission. (2011). Lessen uit recente arbeidsmigratie (LURA). Tweede Kamer, vergaderjaar 2011-2012, 32 680, 4.

Tops, P. (2007). Regimeverandering in Rotterdam. Hoe een stadsbestuur zich opnieuw uitvond. Amsterdam: Uitgeverij Atlas.

Van der Heijden, P. G. M., Cruijf, M., \& Van Gils, G. (2013). Aantallen geregistreerde en niet-geregistreerde burgers uit MOE-landen die in Nederland verblijven. Utrecht: Universiteit Utrecht.

Van Meeteren, M., van de Pol Meeteren, S., Dekker, R., Engbersen, G., \& Snel, E. (2013). Destination Netherlands. History of immigration and immigration policy in the Netherlands. In J. Ho (Ed.), Immigrants: Acculturation, socio-economic challenges and cultural psychology (pp. 113-170). Hauppage: Nova Science publishers.

van Ostaijen, M., \& Scholten, P. (2014). Policy populism? Political populism and migrant integration policies in Rotterdam and Amsterdam. Comparative European Politics, 12(6), 680-699.

van Ostaijen, M., Faber, M., Scholten, P., \& Engbersen, G. (2015). Social consequences of CEE migration. Country report the Netherlands (IMAGINATION Working Paper).

Vertovec, S. (2007). Super-diversity and its implications. Ethnic and racial studies, 30(6), 1024-1054.

Open Access This chapter is licensed under the terms of the Creative Commons Attribution 4.0 International License (http://creativecommons.org/licenses/by/4.0/), which permits use, sharing, adaptation, distribution and reproduction in any medium or format, as long as you give appropriate credit to the original author(s) and the source, provide a link to the Creative Commons license and indicate if changes were made.

The images or other third party material in this chapter are included in the chapter's Creative Commons license, unless indicated otherwise in a credit line to the material. If material is not included in the chapter's Creative Commons license and your intended use is not permitted by statutory regulation or exceeds the permitted use, you will need to obtain permission directly from the copyright holder.

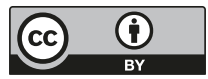

